\title{
Dominanční hierarchie
}

\author{
Eva Jozífková ${ }^{1}$ - Martina Koláčková ${ }^{2}$ \\ 1 Katedra biologie, Přírodovědecká fakulta, Univerzita J. E. Purkyně v Ústí nad Labem \\ 2 Ústav klinické imunologie a alergologie, Lékařská fakulta, Univerzita Karlova v Hradci Králové
}

Do redakce doručeno 24. ř́ijna 2020; k publikaci přijato 1. prosince 2020

\section{DOMINANCE HIERARCHY}

ABSTRACT Dominance hierarchy has evolved as an adaptation of socially living beings to environmental surroundings. Even today, the evolutionary history of humans influences modern people of Euro-American societies. Here we 1) briefly explain the function and evolutionary background of dominance hierarchy in terms of behavioral sciences, 2) characterize features of dominance hierarchy in humans, and 3) give examples of how the dominance rank is established in humans, how it affects the life of an individual, and is manifested in human behavior. Hierarchical structure, rank establishment and limitations given by the rank are predictable. Rank limits the individual in many ways (such as reproduction, communication, health, stress and behavioral patterns). Specialists should bear in mind the existence of social hierarchy between individuals, and between groups of individuals, to fully understand human behavior, decisions and feelings.

KEY WORDS dominance hierarchy; hierarchy; dominance; submissiveness; society; social organization; social hierarchy; human

ABSTRAKT Dominanční hierarchie se vyvinula jako adaptace sociálně žijících živočichů na podmínky prostředí. Postavení v dominanční hierarchii výrazně ovlivňuje život a chování člověka i v dnešních moderních evropských a amerických společnostech. Zde 1) stručně vysvětlíme principy a evoluční pozadí dominanční hierarchie z úhlu pohledu behaviorálních věd, 2) popíšeme rysy dominanční hierarchie u člověka, a 3) uvedeme př́klady toho, co určuje hierarchické postavení jedince u člověka, jak toto postavení ovlivňuje život jedince a jak se projevuje v chování.

Struktura dominanční hierarchie, ustavení hierarchického postavení (rank) a omezení daná tímto postavením jsou předvídatelná. Postavení ovlivňuje život jedince v mnoha směrech (reprodukce, komunikace, zdraví, tok informací, vzorce chování). Pokud chceme plně porozumět chování člověka, jeho rozhodnutím a pocitům, musíme brát v úvahu existence dominanční hierarchie mezi jedinci a mezi skupinami jedinců.

KLÍČOVÁ SLOVA dominanční hierarchie; hierarchie; dominance; submisivita; společnost; uspořádání společnosti; společenská hierarchie; člověk

\section{ÚVOD}

Jednou z adaptací člověka je vytváření societ a spolužití ve skupinách. Život v societě však podléhá určitým pravidlům. Zřetelně vnímáme hierarchické uspořádání společnosti při studiu historických populací člověka a/nebo populací člověka žijících v podmínkách blízkých původním podmínkám života našeho druhu (u tzv. př́rodních národů) např. (Klindworth Voland 1995; Gibson - Mace 2007; Reyes-Garcia et al. 2008; Morrison et al. 2018).

$\mathrm{Na}$ druhou stranu podle Boehma (2020) lidé vykazují jasně patrnou tendenci $\mathrm{k}$ rovnostářství. Za rovnostářské považuje pravěké i současné populace lovců a sběračů a některá kmenová společenství. Připouští však, že rovnostářství se nemusí vztahovat na všechny členy těchto komunit neomezeně.

Ve skutečnosti se některé prvky chování související s hierarchickým uspořádáním society objevují i v současných euroamerických tzv. westernizovaných společnostech (např. Pratto et al. 2006). V následujícím textu vysvětlíme účel a strukturu dominanční hierarchie živočichů, popíšeme dominanční hierarchii v současných euroamerických společnostech u člověka, doložíme, jak postavení v dominanční hierarchii ovlivňuje chování a život člověka a upozorníme na část rizik, která $\mathrm{z}$ toho vyplývají. 


\section{JAK DOMINANČNÍ HIERARCHIE FUNGUJE}

Dominanční hierarchie je způsob organizace society a/nebo rodiny (Veselovský 2005), který snižuje počet střetů mezi jedinci (Manning - Dawkins 2009) a zajištuje soudržnost skupiny (Veselovský 2005; Jozifkova et al. 2014). I jedinci z jedné skupiny nebo rodiny mají různé zájmy. Konkurují si a dostávají se do sporů. Střet však stojí mnoho sil a může při něm dojít ke zranění. Živočichové, kteří spolu žijí ve skupině, si pamatuji podle minulých zkušeností nebo poznají podle různých znamení (např. barva, velikost těla), s kým by střet nevyhráli. Takovým jedincům ustupují (Manning - Dawkins 2009).

Dominanční hierarchie znamená, že ve skupině došlo $\mathrm{k}$ ustavení sociálních pozic, př̀ kterém někteří jedinci ustupuji ostatním, přičemž jim často poskytují užitečné zdroje bez boje (Alcock 2013). Ponechávají jim například potravu, místa k odpočinku a také sexuálního partnera (Manning - Dawkins 2009). Níže postavení jedinci jsou omezováni výše postavenými jedinci (Manning - Dawkins 2009). Hierarchický žebříček je udržován tím, že nadřízený hrozí podřízenému, podřazeni jedinci se vyhýbají konfliktům $s$ nadřazenými a svoji podřazenost dávají najevo submisivitou.

Postavení jedince v systému závisí především na jeho schopnosti bojovat $(\mathrm{a} /$ nebo získat podporu těch, kteři za něj mohou bojovat). Tak, jak se tyto schopnosti mění během života jedince, mění se i jeho hierarchické postavení. Dominanční hierarchie je tedy dynamický systém (Jozifkova 2014).

Dominanční hierarchie patř́i ke strategiím zajiš̌tujícím přežití $\mathrm{v}$ určitém prostředí. Podle prostředí a způsobu života druhu se liší (Manning - Dawkins 2009) Život v societě je adaptací na podmínky, ve kterých živočich žije a vyvijí se. Podmínky prostředí formují uspořádání society, např́iklad počet jedinců v societě, počet samců a samic, párovací systémy (polygynie, monogamie) i sociální systémy (patriarchát, matriarchát). A tyto faktory úzce souvisís stypem dominanční hierarchie. Možnosti a způsoby, jak se chovat jsou v societě či rodině jsou ovlivněny anebo přímo určeny hierarchickým postavením jedince vůči ostatním. De Waal (2006) použil při popisu chování primátů $\mathrm{v}$ tomto smyslu pojem sociální klec. U člověka může např́íklad také ovlivnit průběh komunikace, objem a kvalitu předávané informace, hraje roli při dvoření a volbě partnera. Šikana a domácí násilí mohou být chápány jako velmi extrémní projevy dominančních hierarchií.

Postavení v dominanční hierarchii ovlivňuje pravděpodobnost přežití jedince a souvisí s širokou škálou projevů jedince. Na hierarchickém postavení záleží, zda jedinec získá potravu, úkryt či bezpečné místo, zda a s kým se může rozmnožit (Jozifkova 2014).

\section{DEFINICE DOMINANČNÍ HIERARCHIE}

Dominanční hierarchii můžeme definovat jako způsob uspořádání society a/nebo rodiny, kdy 1) je snížen počet konfliktů mezi jedinci tak, že 2) jedni ustupují jiným a poskytují jim zdroje bez boje, 3) většinou na základě zkušenosti z předcho- zích agonistických interakcí a 4) tímto způsobem nadřízení jedinci omezují chování podřízených (Jozifkova 2014; Jozifkova \& Kolackova 2020). Jedinec má určitou pozici v hierarchii (hierarchické postavení, rank nebo sociální status). Jako dominance pak bývá označováno vysoké postavení $\mathrm{v}$ hierarchii, podstata získávání nadřízeného podstavení, celý systém uspořádání, nebo schopnost vysoké postavení získat (McFarland 1981; Veselovský 2005; Manning - Dawkins 2009; Alcock 2013). Bývá však také označována tendence usilovat o dosažení vysokého postavení (vlastnost dominance).

Hierarchické postavení - rank (místo, pozice, hodnost) definují Manning a Dawkins (2009) tak, že chování výše postaveného nebo dominantního jedince není omezováno ostatními, zatímco chování podřízených (subordinátních, submisivních) jedincủ je omezováno. Omezení vyplývající z nízkého hierarchického postavení jsou různá, mohou však např́ílad určovat př́stup $\mathrm{k}$ potravě, místům odpočinku, a $\mathrm{k}$ samicím (Manning - Dawkins 2009).

\section{POJMY UŽÍVANÉ VE SPOJENÍ S DOMINANČNÍ HIERARCHIÍ V ETOLOGII}

Hierarchické vztahy se označují jako dominančně-submisivní (De Waal 2006) („dominance-subordination relationships“ (Beaugrand et al. 1996; Franck 1996; Fontani - Maffei 1997)) nebo "dominance-submission relationships“ (Guillemin et al. 2000). Výše postavení jedinci se označují jako dominantní, níže postavení jako subordinátní (Manning - Dawkins 2009) nebo submisivní (Audet - Anisman 2010; Feder et al. 2010; Manteuffel et al. 2010). Nejsilnější dominantní jedinec se označuje alfa, další člen beta, jemu podřízený gama, gamě je podřízená delta, nejniže postavený jedinec je označován omega (Veselovský 2005).

Podř́zený postoj (submissive posture (McFarland 1981)) brzdí negativní projevy vnitrodruhového agresivního chování, zastavuje nebo snižuje agresivitu mezi př́ślušníky stejného druhu v situaci, kdy je útěk znemožněn nebo nevýhodný (Veselovský 2005). Usmiřovací chování (appeasement behavior, (McFarland 1981)) nebrzdí agresivní chování, ale odblokuje jiné okruhy chování (Veselovský 2005).

\section{STRUKTURA DOMINANČNÍ HIERARCHIE U ŽIVOČICHŮ}

V úvodu zmíněný „peck order“" u slepic je př́ikladem lineární hierarchie (McFarland 1981). Jedna ze slepic tedy byla dominantní v tom smyslu, že mohla odehnat všechny ostatní. Následovala slepice, která mohla odehnat všechny ostatní s výjimkou první. Nejníže postavená slepice byla odháněna všemi ostatními (Manning - Dawkins 2009). Ve větších skupinách, kde se jedinci nemohou osobně znát, dochází $\mathrm{k}$ tzv. neúplné hierarchii. Rozpoznáme vedoucího jedince nebo ty výše postavené, ale základna je naznačena jen nejasně (Franck 1996). U některých druhů může být situace složitější. Zvirire 
$A$ je nadřazeno zvířeti $\mathrm{B}$, které je nadřazeno zvířeti $\mathrm{C}$, přitom však A nemusí být nadřazeno zvířeti C (Manning - Dawkins 2009). Existují tedy trojúhelníkovité vztahy (Franck 1996) nebo tzv. kruhové hierarchie (Nakamichi - Koyama 1997).

Rízení celé skupiny nemusí být záležitostí jednoho jedince. Společenskou formaci může řídit několik zkušených zvírat. (Veselovský 2005) Jedná se o koaliční zpưsob řizení.

Sociální hierarchie se může týkat všech členů společnosti nebo může být pro každé pohlaví oddělená, jako např́íklad u vlků, paviánů, makaků a králíků (Veselovský 2005).

Oddělená je v situaci, kdy jedinci každého pohlaví kompetují o odlišné zdroje. Například u volně žijících králíků Oryctolagus cuniculus jsou hierarchie samců a samic oddělené (samci mezi sebou kompetují o samice, samice mezi sebou soutěží o nejlepší místa k vybudování nory) (Vervaecke et al.2010). Sourozenecké skupiny domestikovaného králíka Oryctolagus cuniculus $f$. domesticus (plemeno novozélandský) chované na malém prostoru vytvářely lineární hierarchie pro obě pohlaví dohromady.

Jednotlivé druhy lze rozdělit na „tolerantni“ a „despotické“ podle toho, jak strmý je gradient dominance (dominance gradient) (Jacobs et al. 2011), tedy podle strmosti hierarchie (steepness of the hierarchy) (Vervaecke et al.2010). Čím je hierarchický rozdíl mezi nadřazeným a podřazeným jedincem větší, tím je hierarchie strmější.

\section{ZRANĚNÍ NEJSOU NUTNÁ, ALFA NENÍ DIKTÁTOR, AGRESIVITA NENÍ DOMINANCE}

Vysoký status jedinci nezískávají jen na základě vítězství ve skutečném boji, nýbrž také na základě výhry v ritualizovaném souboji (McFarland 1981). Ritualizovaný souboj je boj podle vrozených pravidel, kdy pravděpodobnost zranění snížena (Veselovský 2005). Jedinci mohou také získat status pozitivními interakcemi, jako je například vzájemná péče o povrch těla (mutual grooming) (Manning - Dawkins 2009). Vedoucí jedinec (leader) je ten jedinec, který je v čele pohybující se skupiny (Ihl - Bowyer 2011). Iniciátor (iniciator) je ten, kdo započíná s aktivitou a ostatní ho $\mathrm{v}$ této aktivitě následují. V obou případech nemusí jít o nejvýše postavené jedince. Mưže to být starší jedinec, který zná nejlépe prostředí (Jacobs et al. 2011). Různí jedinci mohou vést při různých činnostech (Jacobs et al. 2011).

I živočichové mohou hlasovat, například krávy buvola kaferského hlasovaly o dalším pohybu stáda natočením těla preferovaným směrem (Davies et al. 2012). Hlas výše postaveného však má v těchto př́ípadech větší váhu (krávy (Sarova et al. 2010), psi hyenovití (Grim 2010)).

Jednání nejvýše postaveného jedince může být zpětně kontrolováno skupinou, jak pozoroval de Waal (2006) u šimpanzů (Pan troglodytes, šimpanz učenlivý). Když alfa samec př́liš pronásledoval jiného samce, začalo několik samic protestně poštěkávat a ostatní včetně nejvýše postavené samice se přidaly. Alfa samec pak svůj útok přerušil.

Obdobně holubi letěli jinam, než kam je vedl leader, pokud si mysleli, že je nevede správným směrem (Watts et al. 2016). Agresivní chování nebo tendence $\mathrm{k}$ tomuto chování může pomoci zvýšit hierarchické postavení (Alcock 2013), zejména v okamžiku, kdy se sociální hierarchie ustavuje. Agresivita však není totéž, co schopnost dosáhnout a udržet si určité hierarchické postavení.

\section{ČÍM JE DÁNO A CO OVLIVŇUJE HIERARCHICKÉ POSTAVENÍ U ŽIVOČICHŮ OBECNĚ}

U živočichů postavení v sociální hierarchii určují vlastnosti, které př́mo ovlivňují schopnost jedince „vyhrát“ ve střetech. Mezi základní faktory u živočichů patří zdatnost a kondice (zdravotní stav, ř́je, věk), pohlaví, zkušenosti, a hierarchické postavení rodiče (např. postavení „děděné“ po matce), prŕíslušnost k rodině/klanu, partnerský svazek (zda existuje či nikoliv) i hierarchické postavení partnera (Lemmon et al. 1997), schopnost ovlivnit chování jiných (manipulace, kooperace), (Borries et al. 1991; Alados - Escos 1992; Veselovský 2005; Curry et al. 2007) a osobnost (personality) (Colleter - Brown 2011) včetně agresivity a vrozené tendence $\mathrm{k}$ dominanci nebo submisivitě (tj. vlastnost dominance) (Feder et al. 2010). Výsledné postavení pak může být dáno faktorem významným pro konkrétní druh nebo kombinací těchto faktorů.

Hierarchické postavení ovlivňuje život jedince zejména následujícím způsobem. Zabezpečuje výše postaveným př́istup ke zdrojům - potravě, vodě, úkrytům, teritoriím a partnerům pro kopulaci a umožňuje jim získat místa chráněná proti predaci či parazitům. Díky tomu mohou výše postavení zvýšit svoji fitness. Na druhou stranu dosažení a udržení hierarchického postavení je spojeno se značnými energetickými náklady. Nejvýše postavení zajištují vnitřní stabilitu skupiny, chrání skupinu (kterou většinou tvoří jejich sexuální partneři a potomci, zvyšují si tedy jejich ochranou svůj reprodukční úspěch) a podílejí se na zajištění zdrojů významných pro skupinu. Často se podílejí na rozhodování a jejich zkušenosti mohou být pro skupinu zásadním prínosem (Veselovský 2005). Níže postaveným pak umožňuje soužití se skupinou přežít, podílet se na reprodukci či zvýšit svou fitness nepřímo podporou prríbuzných.

\section{DOMINANČNÍ HIERARCHIE U ČLOVĚKA}

Lidská společnost má tendenci organizovat se do hierarchie (Sapolsky 2019), kdy členové určitých skupin mají vyšší sociální status a moc než členové jiných (Pratto et al. 2006).

Pro současné moderní euroamerické populace je typické:

1) neoddělování hierarchií podle pohlaví. Autoři zaznamenali mírně vyšší postavení mužů oproti ženám (Sidanius et al. 1994; Rubin 2000; Carli 2001; Helweg-Larsen et al. 2004), jedná s však o starší studie a společnost v tomto směru nyní prochází změnami. Dospělí mají ve společnosti větší moc než děti (Pratto et al. 2006).

2) Existence hierarchií v menších skupinách (rodina, bydliště, 
pracoviště, zájmová skupina, nemocnice), z nichž do některých jedinec vstupuje dobrovolně, a kde osoby mohu zaujímat do různé míry na sobě nezávislá hierarchická postavení. Člověk prochází v průběhu dne celou řadou statusů (Soukup 2011) a může se ocitat ve velmi rozdílných pozicích (Sapolsky 2019). V těchto skupinách dochází $\mathrm{k}$ tvorbě koalic mezi jedinci. Tyto hierarchie vznikají i v prostředí internetu. (viz niže (Rubin 2000; Dunbar - Barrett 2007; Ocker 2007; Soukup 2011; Warren et al. 2012)).

3) Existence skupin jedinců s určitou charakteristikou, vlastností, kteří na základě této charakteristiky stojí výše (Pratto et al. 2006). Např́ílad výše stojí jedinci s vyšším socioekonomickým statusem. Mezi níže postavené (stigmatizované) skupiny mohou patřit osoby s mentálním onemocněním, jedinci s nadváhou, nebo například i jedinci s odlišným sexuálním zaměřením (Ortiz-Hernandez 2005; Evans-Lacko et al. 2012; Levy - Pilver 2012; Wight et al. 2012).

4) Vznik uskupení velkého počtu jedinců s neúplnou hierarchií (obyvatelé velkoměsta $\mathrm{v}$ hromadné dopravě) a větších uskupení jedinců se stejnými charakteristikami (dvě tř́dy dětí jednoho věku apod.), které mohou rovněž vykazovat neúplnou hierarchii. $\mathrm{V}$ období vzniku člověka jako druhu se však pravděpodobně vyskytovaly society (skupiny, tlupy) o menším počtu jedinců (viz Rubin (2000)).

5) Existují různě strmé hierarchie tedy různě př́sná pravidla regulující vzájemné chování členů různých skupin vůči sobě a různě strmé hierarchie určující chování členů vưči sobě uvnitř skupiny (viz (Pratto et al. 2006; Lindova 2009; Sapolsky 2019). Výrazně se mohou skupiny lišit i v rámci jedné populace. 6) Jedinci mohou preferovat určité postavení $v$ hierarchickém žebřičku uvnitř menší skupiny. Mohou preferovat vy̌šši i nižší postavení, např́klad v závislosti na tendenci dominovat (vlastnost dominance). Preference pro nižší postavení nebyla podle dostupných studií vždy spojena se ztrátou nebo nevýhodou. Páry, kde se jeden z partnerů podřizoval druhému, měly více dětí nebo více synů (Jozifkova et al. 2014). A to bez ohledu na to, jestli byl níže postavený jedinec muž nebo žena. Při jiném experimentu si v roli šéfa vedli lépe ti, kteří si na začátku experimentu přáli tuto roli zaujmout (Mast 2010).

7) Dočasně se může objevit tzv. obrácená hierarchie sociální nadvlády ${ }^{2}$. Boehm (2020) takto nazývá situaci, kdy se níže postavení členové spojí do skupin a ovládají výše postavené jedince. Připisuje ji pủvodním a některým kmenovým společenstvům. Jevy jako petice, vlna kritiky nebo přijetí na sociálních sítích, vyjadřování souhlasu či nesouhlasu masivního počtu osob, kdy jedinci svým sdružováním do početných názorových skupin vyvolají požadované jevy, by mohly být př́ikladem takového chování v současnosti.

\section{CO URČUJE POSTAVENÍ V HIERARCHII U ČLOVĚKA}

U člověka ovlivňovalo postavení $\mathrm{v}$ hierarchii pohlaví, zdravotní stav a kondice, věk, fyzické atributy jako výška, rysy tváře, hloubka hlasu, dále pak sexuální atraktivita (především u žen), hierarchické postavení rodiče, hierarchické postavení partnera, př́slušnost ke klanu, schopnost kontrolovat zdroje a teritorium, schopnost ovlivnit chování jiných, zkušenost, a tendence $k$ dominanci nebo submisivitě jako rys osobnosti, a některé další rysy osobnosti. Jedná se tedy opět o faktory, které ovlivňují schopnost jedince vyhrávat $\mathrm{v}$ interakcích mezi jedinci a/nebo získat dostatečnou podporu těch, kteří jsou schopni $\mathrm{v}$ těchto interakcích vyhrávat.

Muži dosahovali vyšších hodnot sociální dominance než ženy (Sidanius et al. 1994). Osoby s mentálním onemocněním nebo např́klad jedinci s nadváhou a např́ílad i jedinci s odlišným sexuálním zaměřením stáli níže (Evans-Lacko et al. 2012; Levy - Pilver 2012; Wight et al. 2012). Děti stojí níže než dospělí (Pratto et al. 2006).

Vyšší a tělesně zdatněǰśi osoby zaujímaly vyšší postavení (von Rueden et al. 2008). Muži s maskulinnějšími tvářemi (Perrett et al. 1998) a osoby s hlubokým hlasem byly vnímány jako dominantnější (Judge - Cable 2004; Wolff - Puts 2010; Klofstad et al. 2012). Afroameričané $\mathrm{s}$ tmavší pletí měli v USA oproti Afroameričanům se světlejší pletí nižší socioekonomický status a nižší prestiž (Hochschild - Weaver 2007).

Atraktivnějšś ženy získávaly vy̌šśi vliv (Haas - Gregory 2005). U mužů na rozdíl od žen je atraktivita podmíněna znaky spojovanými s vy̌ším statusem (Evans et al. 2008) Tedy atraktivní je ten muž, který má vysoký socioekonomický status. Zatímco žena je považována za atraktivní, pokud vykazuje fyzické znaky, které souvisí s vy̌ší plodností (Buss 2016).

Při popisu postavení jedince nebo rodiny $\mathrm{v}$ širší společnosti bývá často používán pojem socioekonomický status. Ten většinou zahrnuje př́ijem, vzdělání, zaměstnání a majetek. Takto definovaný socioekonomický status souvisí se schopností získávat a kontrolovat zdroje, což jej spojuje s dominanční hierarchií.

Stupeň vzdělání dítěte byl ovlivněn socioekonomickým statusem jeho rodiče (Korupp et al. 2002). Ženy upřednostňovaly muže s vysokým statusem jako partnery pro dlouhodobé vztahy (Gueguen - Lamy 2012; Ha et al. 2012). Takovým způsobem mohou zlepšit postavení svých potomkủ. Jedinci rovněž mohou získat podporu od úspěšnějších členů klanu (Lawson - Saltmarshe 2002).

Teritoriem a zároveň zdrojem může být vlastnictví půdy (Voland et al. 1991; Klindworth \& Voland 1995; Voland - Dunbar 1995), zdrojem může být vlastnictví dobytka (Guliye et al. 2007).

Co se týče schopnosti tvořit koalice, $u$ kmene Tsimane měli muži $s$ velkou sociální podporou vliv i respekt (von Rueden et al. 2008). Jedinci s vysokým stupněm tendence $\mathrm{k}$ dominanci (tj. „dominance“ jako vlastnost měřená podle psychologických testů) získávali vliv ve skupině, protože se chovali tak, že se ostatním jevili jako kompetentní, přestože jim způsobilost nebo schopnosti chyběly (Anderson - Kilduff 2009).

\section{JAK HIERARCHICKÉ POSTAVENÍ OVLIVŇUJE ŽIVOT ČLOVĚKA}

Hierarchické postavení ovlivňuje život jedince, jeho pravděpodobnost přežití a jeho reprodukční úspěch. Vyšší hierar- 
chické postavení je spojeno s vyšší pravděpodobností přežití, protože výše postavení se přednostně dostanou ke zdrojům jako je kvalitní potrava, bezpečná místa a vhodné životní prostředí. Jedinci výše postavení jsou z pohledu evoluční biologie nositeli genů, které obstály v konkurenci s jinými geny. Proto jsou výše postavení upřednostňování jako partneři $\mathrm{k}$ reprodukci, získávají kvalitnější partnery a díky tomu i díky př́istupu ke zdrojům jejich potomci přežívají s vyšší pravděpodobností. Výše postavení jedinci tedy mají vyšší fitness.

Např́iklad výše postavení muži kmene Tsimane žijících v Amazonii vykazovali lepší výživný stav (Reyes-Garcia et al. 2008). Studie, ve které autoři hledali příčiny nízké porodní váhy v oblasti plání v Nepálu, prokázala, že nejmladší snachy později vařily a jedly méně než ostatní členové domácnosti (Morrison et al. 2018). V Etiopii byly děti prvních žen, které jsou nejvýše postavené, lépe živené než děti druhých a třetích žen (Gibson - Mace 2007).

Výše postavení lidé v Indii měli přístup k lékařské péči (Maharani - Rahardjo 2012) a tedy vyšší pravděpodobnost přežití. Tento efekt byl však zaznamenán i ve vysoce rozvinutých společnostech. Lidé starší 64 let s vyšším socioekonomickým statusem přežívali déle $\mathrm{v}$ Japonsku (Hasegawa et al. 2011). V Hong-Kongu bylo u osob s nízkým socioekonomickým statusem zaznamenáno více úmrtí spojených s vysokou teplotou prostředí (Chan et al. 2012).

Co se týče bezpečného prostředí, např́iklad v ghettech Afroameričanů v USA byla zaznamenána nižší průměrná délka života mužů (Barrett et al. 2007). Kratší průměrnou dobu života mužů skupiny Black oproti mužům skupiny White zaznamenala i novější studie (pojmy převzaty z originální studie (Bond - Herman 2016)).

Výše postavení členové církve (Mealey 1985), i mužští pracovníci univerzit (Fieder et al. 2005) měli více potomků. Muži výše postavení v mormonské církvi měli více manželek (Mealey 1985), muži ve vedoucích pozicích měli více dětí než ostatní pracovníci univerzity (Fieder et al. 2005).

$\mathrm{V}$ polygynních společnostech bylo vyšší postavení muže spojené s nižší mortalitou jeho potomků, zatímco v monogamních společnostech souvisel reprodukční úspěch výše postavených mužů s kvalitou jejich žen (von Rueden - Jaeggi 2016). Muži s vyšším statusem uváděli vyšší frekvenci kopulací (Perusse 1993). Výše postavení muži měli atraktivnější, tedy plodnější partnerky či partnerky s kvalitními geny (Borkenau 1993; Grammer - Thornhill 1994; Barber 1998; Jones et al. 2001; Jasienska et al. 2004; Buss - Shackelford 2008).

Na druhé straně muži s nízkým socioekonomickým statusem, tedy ti, kteří mohli s nízkou pravděpodobností získat partnerku, se častěji uchylovali ke znásilnění (Thornhill - Thornhill 1992; Thornhill - Palmer 2000) jako k alternativní strategii.

Vysoký status - sociální dominance - u samců úzce souvisel se symetrií těla či odolností k nemocem (Gangestad et al. 1994; Grammer - Thornhill 1994; Sidanius et al. 1994; Jones et al. 2001; Waynforth 2001; Soler et al. 2003; Thornhill - Gangestad 2006), a př́stupem ke zdrojům (Akkerhuis - Damgaard 1999), a tedy následně s reprodukčním úspěchem (Deruiter - vanHooff 1993).
Ženy přitahovali muži, kteří vykazovali znaky vysokého hierarchického postavení, jako je vysoký sociální status (Mealey 1985; Mazur et al. 1994; Fieder et al. 2005), tváŕ s rysy typickými pro dominantní osoby (Mueller - Mazur 1997; Booth - Mazur 1998), fyzická dominance (Wolff - Puts 2010), maskulinní hlas (Feinberg et al. 2006), a přitahovala je vưně dominantních mužů (Havlicek et al. 2005). Část osob má však opačné preference - některé ženy volí submisivní muže a submisivní muži je sexuálně vzrušují (Jozifkova et al. 2014; Jozifkova - Kolackova 2017; Jozifkova 2018). Páry, kde se jeden z partnerů podřizoval druhému, měly vyšší reprodukční úspěch nezávisle na pohlaví výše postaveného jedince, takže se $\mathrm{z}$ evolučně biologického hlediska jedná o úspěšnou strategii (Jozifkova et al. 2014).

V průzkumu prováděném v České republice přibližně polovinu osob sexuálně vzrušovalo, když se jim partner podřizoval a/ nebo když se podřizovali partnerovi. Silnou preferenci vykazovalo $8,2 \%$ osob a $6,1 \%$ dokonce nevzrušovala rovnost partnerů vůbec. Většinu mužů vzrušovaly submisivní ženy a většinu žen dominantní muži. Avšak 3,4\% žen vzrušovala submisivita mužů a 6,1 \% mužů dominance žen (Jozifkova 2018).

\section{STRES, NEMOC A SEBEVRAŽDY}

Jedinec je při snaze získat či udržet hierarchické postavení vystaven stresu. Jako stresující faktor působí i nízké postavení samo o sobě, zvláště pokud je jedinci nadřazeno větší množství osob. Nízké postavení je spojováno se zhoršeným zdravotním stavem a pocity deprese. Obdobně působí i vyloučení ze society nebo nedostatek kontaktu s ostatními členy society. Sapolsky (2005) došel k zajímavému závěru, když hledal odpověd’ na otázku, zda jsou více stresovaní výše či níže postavení jedinci. Výše postavení jedinci byli vystaveni vysokému stresu v situaci, kdy se snažili své postavení uhájit. Na druhou stranu níže postavení byli stresováni opakovanými útoky nadrazených (Sapolsky 2005).

Hierarchické postavení jedince má vliv na hladiny hormonů a zdravotní stav jedince. Výše postavení vojáci měli vyšší hladinu kortizolu nežli níže postavení, pokud uvěřili, že je níže postavení schválně nevystřídali na stráži (Siart et al. 2016). V jiném experimentu autoři manipulovali s hierarchickým postavením jedince a mírou dominantního chování jeho oponenta. Účastníkům s nízkým postavením se výrazněji zvýšil tlak. Těm, kteří museli jednat s dominantnějším partnerem, se zvýšil systolický krevní tlak, srdeční frekvence, a vykazovali vyšší změny v parasympatické a sympatické aktivaci srdce. Podle autorů toto pozorování potvrzuje existenci vztahu mezi postavením v dominanční hierarchii a kardiovaskulárním onemocněním (Cundiff et al. 2016). Rozsáhlá studie ze Švédska pak doložila vztah mezi subjektivně pocitovaným sociálním statusem a výskytem zdravotních problémů v populaci pracujících osob. Této studie se účastnilo přes 5 tis. respondentů a u těch, kteř́i měli nižší subjektivní sociální status, byl zaznamenán častější výskyt zhoršeného zdraví (Miyakawa et al. 2012). 
Existuje také přímý vztah mezi nízkou pozicí v sociální hierarchii a vzrůstajícím stresem v závislosti na počtu jedinců ve skupině. Čím větši je počet výše postavených jedinců, tím většímu stresu jsou nejníže postavení jedinci vystaveni. Menší příjem ve srovnání se střední hodnotou (mediánem) v obytných oblastech s populací nad 20000 obyvatel souvisel s vyšší mortalitou mezi těmi se středním a nízkým platem. Avšak obdobná souvislost nebyla nalezena pro menší obce (Elstad et al. 2006). Tato studie proběhla v Norsku.

Níže postavení jedinci mohou trpět zdravotními problémy jen na základě svého postavení (Sapolsky 2005). Tento jev je nazýván socioekonomický gradient (Sapolsky 2005).

Zjednodušeně lze předpokládat, že jedinci na nejnižším hierarchickém umístění v podstatě prohrávají sociální interakce $\mathrm{s}$ výše postavenými. Při prohře v interakci dochází ke zvýšení hladiny kortizolu (viz (Jimenez et al. 2012)) a zvýšená hladina kortizolu má negativní vliv na zdraví člověka (Finn 2007). $\mathrm{S}$ postavením $\mathrm{v}$ hierarchii souvisel např́klad výskyt kardiovaskulárních onemocnění (Cundiff et al. 2016).

Samo snižování hierarchického postavení je spojeno s pocity deprese (Rohde 2001). Podle social rank teory of depression jsou níže postavení jedinci a ti, kteří ztratili své postavení vystavení většímu riziku výskytu deprese než vítězové a osoby s vyšším statusem (Gilbert - Allan 1998). Výsledky studie tento předpoklad podpořily (Gilbert - Allan 1998).

Jedinci, kteří jsou vyloučeni ze society, nebo osaměle žijící osoby čelí velkému stresu. To může vést ke zdravotním problémům (Finn 2007), depresím (Abe et al. 2012; Kelley-Moore et al. 2016) a riziku sebevraždy (Forkmann et al. 2012) a smrti (Finn 2007).

\section{TOK INFORMACÍ}

Hierarchické postavení ovlivňuje způsob komunikace, její délku, průběh, množství předávaných informací, obsah, kvalitu i význam, jaký předávaným informacím jedinec přikládá.

Jedinec se sklonem $\mathrm{k}$ submisivitě nebo jedinec $\mathrm{v}$ postavení podřízeného souhlasí, neodporuje, neprosazuje tlakem svi̊j názor, nevyjadřuje negativní názor, pod nátlakem mění chování, postoje, názory. Jedinec se sklonem $\mathrm{k}$ dominanci nebo jedinec v situaci nadřízeného se nepodřídí, nesouhlasí, odporuje v tvrzení, prosazuje tlakem svůj názor, pod nátlakem nemění chování, postoje, názory (Buss - Craik 1980; Goldberg 1999). Průběh komunikace určuje dominantní jedinec, častěji hovor začíná a hovor končí, určuje délku komunikace a určuje i obsah komunikace (viz (Buss - Craik 1980; Goldberg 1999)). Pokládá otázky, ptá se opakovaně, přerušuje ostatní a vyžaduje informace (Maner - Mead 2010). Níže postavení jedinci poskytovali více informací (Maner - Mead 2010). Na druhou stranu dominantní jedinci vykazovali tendenci nechávat si informace pro sebe (Maner - Mead 2010). V jiném experimentu však respondenti dominantnímu virtuálnímu lékaři poskytli méně informací, méně mluvili a více souhlasili. (Mast et al. 2008).

Pro osoby níže postavené nebo s tendencí k submisivitě je typické, že své zájmy neobhajují natolik důrazně jako jedinci výše stojící či že se své zájmy prakticky neobhajují vůbec, na rozdíl od dominantních, kteří své zájmy prosazují i na úkor jiných (Buss - Craik 1980; Maner - Mead 2010).

Informace v komunikaci se může podstatně měnit podle toho, zda informace směřuje od níže postavené osoby $\mathrm{k}$ osobě výše postavené a naopak. Např́iklad submisivní osoba souhlasí, že udělala chybu, i přes to, že chybu neudělala (Buss - Craik 1980). $\mathrm{V}$ souladu s přirozeným chováním člověka mohou mít třetí osoby tendenci přikládat informaci osob níže postavených či submisivněji se chovajících menší význam než informaci osob působících dominantněji, nebo mohu informaci od dominantněji se projevujících osob považovat za pravdivější. Tato tendence může komplikovat situaci osobám, jejich hierarchické postavení bylo sníženo, např́iklad obětem domácího násilí, šikany nebo bossingu (Jozifkova 2014).

Sapolsky (2019) zdůrazňuje problematickou stránku silné snahy osob vřadit se do hierarchií a přizpůsobit se. Tzv. konformita např́klad zajištuje, že jedinci v societách používají stejné signály. Stojí však i za situacemi, kdy osoby mění svoje správné chování, vnímání jevu, nebo názor proto, že ostatní se v dané situaci chovají jinak nebo si myslí něco jiného (Sapolsky 2019).

\section{DALŠÍ POZOROVANÉ VZORCE CHOVÁNÍ}

Výše postavení jedinci stanovují pravidla (Goldberg 1999), činí rozhodnutí (Freeman et al. 2009), a chrání své zájmy bez ohledu na zájmy ostatních (Maner - Mead 2010). Podřízení jedinci se často neodvažují svoje zájmy chránit. Je pro ně typické, že opomíjejí své potřeby ve prospěch ostatních (Buss Craik 1980) a snaží se vyhovět požadavkům druhých (Henley 1977). Snaží se ostatní potěšit (Gilbert et al. 2003).

Níže postavení za kritiku vinili sebe, zatímco výše postavení vinili ostatní (Gilbert - Miles 2000). Submisivní jedinci pocitovali vinu (O‘Connor et al. 2000), zatímco osoby vyjadřující hněv byly ostatními vnímány jako dominantnější (Hareli et al. 2009). Na druhou stranu výše postavení jedinci byli méně empatičtí (Sherman et al. 2015).

Postavení v dominanční hierarchii ovlivňuje i férovost jednání (Siart et al. 2016). Vojáci níže postavení v armádní hierarchii při experimentu drželi stráž déle než výše postavení (Siart et al. 2016).

Osoby s vysokou hladinou testosteronu a nízkou hladinou kortizolu získávaly vyšší hierarchické postavení s vyšší pravděpodobností (Sherman et al. 2016). Ve hře, při které si respondent mohl zvolit strategii holubice nebo jestřába volili častěji strategii jestřába ti s vyšší hladinou bazálního testosteronu a také ti, kteří měli v době experimentu nižší hladinou kortizolu (Mehta et al. 2017).

Dominantní muži se rozhodovali rychleji než muži s nižší sociální dominancí a tato rychlost souvisela s vyšší aktivitou v konkrétních oblastech mozku (da Cruz et al. 2018).

Domácí násilí, šikana a mobbing jsou v podstatě extrémním projevem dominanční hierarchie, kdy původce násilí cíleně a opakovaně snižuje hierarchické postavení oběti (Jozifkova, 2014) viz Ribbon (2018). Snížené postavení limituje chování 
oběti, což bývá pro jedince bez této zkušenosti obtížné vnímat. Je třeba si uvědomit, že osoby se přirozeně chovají v souladu se svým subjektivně vnímaným hierarchickým postavením, což může v těchto případech komplikovat pomoc.

\section{LIMITY STUDIE}

V tomto př́spěvku byly zkratkovitě shrnuty základní principy vzniku, fungování, a struktury dominanční hierarchie. Zaměřili jsme se na proximální podstatu tohoto chování a použili poznatky z oblasti etologie a behaviorální ekologie živočichů, které poskytují srozumitelný a ucelený náhled na problematiku. U popisu chování člověka jsme se soustředili na jevy, které se uplatňují nejvýrazněji a přednostně jsme popsali ty vzorce chování, které mohou mít negativní účinek na život jedince. Pole současného poznání je však mnohem širší.

\section{ZÁVĚR}

Postavení v dominanční hierarchii výrazně ovlivňuje život i chování člověka i v dnešních moderních společnostech. Tyto projevy jsou spojeny s přirozeným chováním jedincủ, které jim umožnilo přežít, jsou evolučně ukotvené a pravděpodobně je nelze jednoduše obejít nebo smazat. Lze jim však porozumět, pochopit rizika, kterým jedinci čelí, a předvídat je. Znalost principů dominanční hierarchie umožňuje rozpoznat strukturu society, odhadnout vznik a výsledky konfliktů, a také uvědomit si míru stresu, kterému jsou někteř́ jedinci vystaveni. S těmito znalostmi je možné včas podat pomocnou ruku tam, kde je to potřeba.

Navzdory snaze o rovnost stále zůstává řada jevů $\mathrm{v}$ současných euroamerických společnostech hierarchizovaná. Naprostá rovnost jedinců $\mathrm{v}$ societě může být $\mathrm{z}$ biologického hlediska obtížně dosažitelným cílem. Důležité, zásadní a reálně dosažitelné je zmírňování velkých hierarchických rozdílủ, které jsou spojeny s negativními jevy, $\mathrm{z}$ nichž některé popisujeme.

\section{DODATEK}

\section{DOMINANČNÍ HIERARCHIE A PŘIIBUZNÉ POJMY}

Pojem dominanční hierarchie (dominance hierarchy) popisuje uspořádání vzájemného postavení živočichů v societě. $\mathrm{V}$ obdobném smyslu byly používány pojmy „social hierarchy“, "social dominance hierarchy“ (Manning - Dawkins 2009), nebo ve starší literatuře „peck order“, klovací pořádek (McFarland 1981; Veselovský 2005; Manning - Dawkins 2009). Dominanční hierarchie byla pod tímto pojmem popsána v roce 1935 u slepic (Veselovský 2005). U člověka bývá pojem dominanční hierarchie uživán při popis struktury society a postavení jedince vưči jiným jedincủm v societě.

Pojmem „social dominance“ v současnosti (zhruba od roku
2014, podle vyhledávání pomocí klíčových slov v databázi WOS) autoři označují nejčastěji dominanci jedné podskupiny osob nad jinou, ve smyslu teorie sociální dominance (Pratto et al. 2006). Postavení jedince ve společnosti je popisováno pojmy jako socioekonomický status, subjektivně pocitovaný sociální status. Dále jsou použivány pojmy moc, fyzická dominance, a osobnostní rys dominance. Socioekonomický status se částečně $s$ dominanční hierarchií překrývá, osoby $\mathrm{s}$ nižším socioekonomickým statusem bývají v dominanční hierarchii postaveny níže než osoby se statusem vyšším. Nicméně se nejedná o totéž, i osoby se shodným socioekonomickým statusem se mohou lišit postavením v lokální dominanční hierarchii např́klad $v$ rodině nebo na pracovišti. Bliže než socioekonomický status má $\mathrm{k}$ postavení $\mathrm{v}$ dominanční hierarchii pojem subjektivně pocitovaný sociální status (např. (Miyakawa et al. 2012).

Postavení v dominanční hierarchii dobře vystihuje pojem moc (power) (viz (Henley 1995)). Fyzická dominance je dána tělesnými vlastnostmi člověka (síla, výška) (Judge - Cable 2004; von Rueden et al. 2008). Osobnostní rys dominance bývá definován jako schopnost nebo tendence získávat vyšší postavení $\mathrm{v}$ dominanční hierarchii, submisivnost pak bývá vnímána jako opak dominance (např. (Wiggins et al. 1988; Cattell - Cattell 1995; Allan - Gilbert 1997; Grant - France 2001)).

\section{POZNÁMKY}

1 Signály a odznaky statusu

Podle Maninga a Dawkinse (2009) existují dvě cesty. Za prvé, signály jsou nákladné nebo přinejmenším obtížné a dokážou je vydat jen nejsilnější zviřata. (Přesněji, ti silnější či kvalitnější vydávají kvalitnější signál, tedy síla a/nebo kvalita zvířete se odráží v kvalitě signálu.) S tímto řešením se setkáváme $\mathrm{v}$ situaci, kdy se kondice jedince může rychle měnit, např́klad u jelena v říji ze dne na den (Manning - Dawkins 2009).

Za druhé, pokud se živočichové setkávají s př́liš mnoha jedinci, než aby se znali individuálně, posuzují hierarchické postavení podle „odznaků statusu“ (např́klad černé skvrny na hrdle vrabce domácího). Zajímavé je, že ačkoliv tyto odznaky nejsou př́liš nákladné, slabší zvířata „nepodváději“, protože jako „silnější" by musela čelit výzvám silných zviruat, což by pro ně bylo nákladné (Manning - Dawkins 2009).

2 Obrácená hierarchie sociální nadvlády

Boehm (2020) rozlišuje mezi klasickou hierarchií s nejmocnějším jedincem nejvýše, a tzv. obrácenou hierarchií sociální nadvlády, kdy řadoví členové spojení do skupin určují chování nejvýše postavených jedinců. Rozlišuje despotická společenstva, kde "míŕí pyramida moci vzhưru” a společenstva rovnostářská (obrácená hierarchie sociální nadvlády), kdy řadoví členové spojení do skupin "fakticky diktují alfa jedincům”. Upozorňuje také, že struktura society se může převracet $\mathrm{z}$ jednoho stavu do druhého a zpět. Podle něj byli pravěcí lovci schopni potlačovat př́liš dominantní vedení tak, jak to dosud činí žijící lovci a sběrači. Překvapivě považuje antické a moderní demokracie spíše za despotická než rovnostářská společenstva. Zdůvodňuje to tak, že nejvýše postavení mají i v demokraciích možnost použít moc k donucování ostatních (Boehm 2020). 


\section{LITERATURA}

Abe, Y. - Fujise, N. - Fukunaga, R. - Nakagawa, Y. - Ikeda, M. (2012): Comparisons of the prevalence of and risk factors for elderly depression between urban and rural populations in Japan. International Psychogeriatrics, 24, 1235-1241.

Akkerhuis, G.A.J.M. - Damgaard, C. (1999): Using resource dominance to explain and predict evolutionary success. Oikos, 87, 609-614.

Alados, C.L. - Escos, J.M. (1992): The Determinants of Social-Status and the Effect of Female Rank on Reproductive Success in Dama and Cuviers Gazelles. Ethology Ecology \& Evolution, 4, 151-164.

Alcock, J. (2013): Animal Behavior: An Evolutionary Approach. Sinauer Associates: Sunderland.

Allan, S. - Gilbert, P. (1997): Submissive behaviour and psychopathology. British Journal of Clinical Psychology, 36, 467-488.

Anderson, C. - Kilduff, G.J. (2009): Why Do Dominant Personalities Attain Influence in Face-to-Face Groups? The Competence-Signaling Effects of Trait Dominance. Journal of Personality and Social Psychology, 96, 491-503.

Audet, M.C. - Anisman, H. (2010): Neuroendocrine and neurochemical impact of aggressive social interactions in submissive and dominant mice: implications for stress-related disorders. International Journal of Neuropsychopharmacology, 13, 361-372.

Barber, N. (1998): Sex differences in disposition towards kin, security of adult attachment, and sociosexuality as a function of parental divorce. Evolution and Human Behavior, 19, 125-132.

Barrett, L. - Dunbar, R. - Lycett, J. (2007): Evoluční psychologie člověka. Portál: Prague.

Beaugrand, J.P. - Payette, D. - Goulet, C. (1996): Conflict outcome in male green swordtail fish dyads (Xiphophorus helleri): Interaction of body size, prior dominance/subordination experience, and prior residency. Behaviour, 133, 303-319.

Boehm, C. (2020): Hierarchie v pralesích. Academia: Praha.

Bond, M.J. - Herman, A.A. (2016): Lagging Life Expectancy for Black Men: A Public Health Imperative. American Journal of Public Health, 106, 1167-1169.

Booth, A. - Mazur, A. (1998): Testosterone and dominance in men. In: Behavioral and Brain Sciences, pp. 353-397.

Borkenau, P. (1993): Rich Man and Beautiful Woman - 2 Studies on Sex-Differences in Mate Preferences. Zeitschrift fur Sozialpsychologie, 24, 289-297.

Borries, C. - Sommer, V. - Srivastava, A. (1991): Dominance, Age, and Reproductive Success in Free-Ranging Female Hanuman Langurs (Presbytis-Entellus). International Journal of Primatology, 12, 231-257.

Buss, D.M. (2016): Evolutionary Psychology. The New Science Of The Mind. Routledge: New York.

Buss, D.M. - Craik, K.H. (1980): The Frequency Concept of Disposition Dominance and Prototypically Dominant Acts. Journal of Personality, 48, 379-392.

Buss, D.M. - Shackelford, T.K. (2008): Attractive Women Want it All: Good Genes, Economic Investment, Parenting Proclivities, and Emotional Commitment. Evolutionary Psychology, 6, 134-146.

Carli, L.L. (2001): Gender and social influence. Journal of Social Issues, 57, $725-741$.

Cattell, R.B. - Cattell, H.E.P. (1995): Personality Structure and the New 5Th-Edition of the 16Pf. Educational and Psychological Measurement, 55, 926-937.

Colleter, M. - Brown, C. (2011): Personality traits predict hierarchy rank in male rainbowfish social groups. Animal Behaviour, 81, 1231-1237.

Cundiff, J.M. - Smith, T.W. - Baron, C.E. - Uchino, B.N. (2016): Hierarchy and Health: Physiological Effects of Interpersonal Experiences Associated With Socioeconomic Position. Health Psychology, 35, 356-365.

Curry, M.R. - Eady, P.E. - Mills, D.S. (2007): Reflections on mare behavior: Social and sexual perspectives. Journal of Veterinary Behavior-Clinical Applications and Research, 2, 149-157.

da Cruz, J.- Rodrigues, J. - Thoresen, J.C. - Chicherov, V. - Figueiredo, P. Herzog, M.H. - Sandi C. (2018): Dominant men are faster in decision-making situations and exhibit a distinct neural signal for promptness. Cerebral Cortex, 28, 3740-3751.
Davies, N.B. - Krebs, J.R. - West, S.A. (2012): An Intorduction to Behavioural Ecology. Wiley-Blackwell.

De Waal, F. (2006): Dobráci od prírody. Academia:Praha.

Deruiter, J.R. - vanHooff, J.A.R.A. (1993): Male-Dominance Rank and Reproductive Success in Primate Groups. Primates, 34, 513-523.

Dunbar, R.I.M. - Barrett, L. (2007): The Oxford Handbook Of Evolutionary Psychology. Oxford University Press: New York.

Elstad, J.I. - Dahl, E. - Hofoss D. (2006): Associations between relative income and mortality in Norway: a register-based study. European Journal of Public Health, 16, 640-644.

Evans-Lacko, S. - London, J. - Japhet, S. - Rusch, N. - Flach, C. - Corker E. - Henderson, C. - Thornicroft, G. (2012): Mass social contact interventions and their effect on mental health related stigma and intended discrimination. BMC Public Health, 12

Evans, S. - Neave, N. - Wakelin, D. - Hamilton C. (2008): The relationship between testosterone and vocal frequencies in human males. Physiology and Behavior, 93, 783-788.

Feder, Y. - Nesher, E. - Ogran, A. - Kreinin, A. - Malatynska, E. - Yadid, G. - Pinhasov, A. (2010): Selective breeding for dominant and submissive behavior in Sabra mice. Journal of Affective Disorders, 126, 214-222.

Feinberg, D.R. - Jones, B.C. - Law-Smith, M.J. - Moore, F.R. - DeBruine, L.M. - Cornwell, R.E. - Hillier, S.G. - Perrett, D.I. (2006): Menstrual cycle, trait estrogen level, and masculinity preferences in the human voice. Hormones and Behavior, 49, 215-222.

Fieder, M. - Huber, S. - Bookstein, F.L. - Iber, K. - Schafer, K. - Winckler, G. - Wallner, B. (2005): Status and reproduction in humans: New evidence for the validity of evolutionary explanations on basis of a university sample. Ethology, 111, 940-950.

Finn, M.V. (2007): Evolution of stress response to social threat. In: The Oxford Handbook of Evolutionary Psychology (eds. by Dunbar, R. - Barrett, L.), pp. 273-295. Oxford University Press: New York.

Fontani, G. - Maffei, D. (1997): Hippocampal electrical activity during development and following the establishment of a dominance-subordination relationship in rabbits. Ethology Ecology \& Evolution, 9, 345-359.

Forkmann, T. - Brahler, E. - Gauggel, S. - Glaesmer, H. (2012): Prevalence of Suicidal Ideation and Related Risk Factors in the German General Population. Journal of Nervous and Mental Disease, 200, 401-405.

Franck, D. (1996): Etologie. Karolinum: Praha.

Freeman, J.B. - Rule, N.O. - Adams, R.B. - Ambady, N. (2009): Culture shapes a mesolimbic response to signals of dominance and subordination that associates with behavior. Neuroimage, 47, 353-359.

Gangestad, S.W. - Thornhill, R. - Yeo, R.A. (1994): Facial Attractiveness, Developmental Stability, and Fluctuating Asymmetry. Ethology and Sociobiology, 15, 73-85.

Gibson, M.A. - Mace, R. (2007): Polygyny, reproductive success and child health in rural Ethiopia: Why marry a married man? Journal of Biosocial Science, 39, 287-300.

Gilbert, P. - Allan, S. (1998): The role of defeat and entrapment (arrested flight) in depression: an exploration of an evolutionary view. Psychological Medicine, 28, 585-598.

Gilbert, P. - Cheung, M. - Grandfield, T. - Campey, F. - Irons, C. (2003): Recall of threat and submissiveness in childhood: Development of a new scale and its relationship with depression, social comparison and shame. Clinical Psychology and Psychotherapy, 10, 108-115.

Gilbert, P. - Miles, J.N.V. (2000): Sensitivity to Social Put-Down: it's relationship to perceptions of social rank, shame, social anxiety, depression, anger and self-other blame. Personality and Individual Differences, 29, 757-774.

Goldberg, L.R. (1999): A broad-bandwidth, public domain, personality inventory measuring the lower-level facets of several five-factor models. In: Personality Psychology in Europe (eds. by Mervielde, I. - Deary, I. - De Fruyt, F. - Ostendorf, F.), pp. 7-28. Tilburg University Press: Tilburg.

Grammer, K. - Thornhill, R. (1994): Human (Homo sapiens) Facial Attractiveness and Sexual Selection: The Role of Symmetry and Averageness. In: Journal of Comparative Psychology, 108(3), 233-242.

Grant, V.J. - France, J.T. (2001): Dominance and testosterone in women. Biological Psychology, 58, 41-47.

Grim, T. (2010): Lov kýchajících demokratů. Vesmír, 98.

Gueguen, N. - Lamy, L. (2012): Men's Social Status and Attractiveness Wo- 
men's Receptivity to Men's Date Requests. Swiss Journal of Psychology, 71, 157-160.

Guillemin, M.L. - Atramentowicz, M. - Charles-Dominique, P. (2000): Dominance relationships in captive male bare-tailed woolly opossum (Caluromys philander, Marsupialia : Didelphidae). Revue D Ecologie-la Terre et la Vie, 55, 337-349.

Guliye, A.Y. - Noor, I.M. - Bebe, B.O. - Kosgey, I.S. (2007): Role of camels (Camelus dromedarius) in the traditional lifestyle of Somali pastoralists in northern Kenya. Outlook on Agriculture, 36, 29-34.

Ha, T. - van den Berg, J.E.M. - Engels, R.C.M.E. - Lichtwarck-Aschoff, A. (2012): Effects of Attractiveness and Status in Dating Desire in Homosexual and Heterosexual Men and Women. Archives of Sexual Behavior, $41,673-682$.

Haas, A. - Gregory, S.W. (2005): The impact of physical attractiveness on women's social status and interactional power. Sociological Forum, 20, $449-471$.

Hareli, S. - Shomrat, N. - Hess, U. (2009): Emotional Versus Neutral Expressions and Perceptions of Social Dominance and Submissiveness. Emotion, 9, 378-384.

Hasegawa, T. - Hosh,i T. - Nakayama, N. - Bosako, Y. - Takahashi, T. - Sakurai, N. - Tomoyama, G. - Kurimori, S. - Yoshinori, F. (2011): The Effects of Socioeconomic Status and Lifestyle on Life Expectancy: A Structural Analysis of an Elderly Japanese Population. International Medical Journal, 18, 261-264.

Havlicek, J. - Roberts, S.C. - Flegr, J. (2005): Women's Preference for Dominant Male Odour: Effects of Menstrual Cycle and Relationship Status. Biology Letters, 1, 256-259.

Helweg-Larsen, M. - Cunningham, S.J. - Carrico, A. - Pergram, A.M. (2004): To nod or not to nod: An observational study of nonverbal communication on and status in female and male college students. Psychology of Women Quarterly, 28, 358-361.

Henley, N.M. (1977): Body politics: Power, sex and nonverbal communication. Prentice-Hall: Englewood Cliffs, New Jersey (USA).

Henley, N.M. (1995): Body politics revisited: What do we know today? In: Gender, power, and communication in human relationships (eds. by Kalbfleisch, PJ - Cody, MJ), pp. 27-61. Erbaum: Hillsdale.

Hochschild, J.L. - Weaver, V. (2007): The skin color paradox and the American racial order. Social Forces, 86, 643-670.

Chan, E.Y.Y. - Goggins, W.B. - Kim, J.J. - Griffiths, S.M. (2012): A study of intracity variation of temperature-related mortality and socioeconomic status among the Chinese population in Hong Kong. Journal of Epidemiology and Community Health, 66, 322-327.

Ihl, C. - Bowyer, R.T. (2011): Leadership in mixed-sex groups of muskoxen during the snow-free season. Journal of Mammalogy, 92, 819-827.

Jacobs, A. - Watanabe, K. - Petit, O. (2011): Social Structure Affects Initiations of Group Movements but Not Recruitment Success in Japanese Macaques (Macaca fuscata). International Journal of Primatology, 32, $1311-1324$.

Jasienska, G. - Ziomkiewicz, A. - Ellison, P.T. - Lipson, S.F. - Thune, I. (2004): Large breasts and narrow waists indicate high reproductive potential in women. Proceedings of the Royal Society of London Series BBiological Sciences, 271, 1213-1217.

Jimenez, M. - Aguilar, R. - Alvero-Cruz, J.R. (2012): Effects of victory and defeat on testosterone and cortisol response to competition: Evidence for same response patterns in men and women. Psychoneuroendocrinology, $37,1577-1581$

Jones, B.C. - Little, A.C. - Penton-Voak, I.S. - Tiddeman, B. - Burt, D.M. Perrett, D.I. (2001): Facial symmerty and judgements of apparent health - Support for a "good genes" explanation of the attractiveness-symmetry relationship. In: Evolution and Human Behavior, pp. 417-429.

Jozifkova, E. (2014): Úvod do etologie sociální hierarchie: základní principy dominance a submisivity v biologii chování. Habilitační práce: Masarykova univerzita.

Jozifkova, E. (2018): Sexual Arousal by Dominance and Submissiveness in the General Population: How Many, How Strongly, and Why? Deviant Behavior, 39, 1229-1236.

Jozifkova, E. - Kolackova, M. (2017): Sexual arousal by dominance and submission in relation to increased reproductive success in the general population. Neuroendocrinology Letters, 38, 381-387.
Jozifkova, E. - Kolackova, M. (2020): Dominance Hierarchy. In: Encyclopedia of Evolutionary Psychological Science (eds. by Shackelford, TK - WeekesShackelford, VA), pp. 1-5. Springer International Publishing: Cham.

Jozifkova, E. - Konvicka, M. - Flegr, J. (2014): Why do some women prefer submissive men? Hierarchically disparate couples reach higher reproductive success in European urban humans. Neuroendocrinol Lett, 35, 594-601.

Judge, T.A. - Cable, D.M. (2004): The effect of physical height on workplace success and income: Preliminary test of a theoretical model. Journal of Applied Psychology, 89, 428-441.

Kelley-Moore, J.A. - Cagney, K.A. - Skarupski, K.A. - Everson-Rose, S.A. de Leon, C.F.M. (2016): Do Local Social Hierarchies Matter for Mental Health? A Study of Neighborhood Social Status and Depressive Symptoms in Older Adults. Journals of Gerontology Series B-Psychological Sciences and Social Sciences, 71, 369-377.

Klindworth, H. - Voland, E. (1995): How Did the Krummhorn Elite Males Achieve Above-Average Reproductive Success. Human Nature-an Interdisciplinary Biosocial Perspective, 6, 221-240.

Klofstad, C.A. - Anderson, R.C. - Peters, S. (2012): Sounds like a winner: voice pitch influences perception of leadership capacity in both men and women. Proceedings of the Royal Society B-Biological Sciences, 279, 2698-2704.

Korupp, S.E. - Ganzeboom, H.B.G. - Van der Lippe, T. (2002): Do mothers matter? A comparison of models of the influence of mothers' and fathers' educational and occupational status on children's educational attainment. Quality \& Quantity, 36, 17-42.

Lawson, C.W. - Saltmarshe, D.K. (2002): The psychology of economic transformation: The impact of the market on social institutions, status and values in a northern Albanian village. Journal of Economic Psychology, 23, 487-500.

Lemmon, D. - Withiam, M.L. - Barkan, C.P.L. (1997): Mate protection and winter pair-bonds in black-capped chickadees. Condor, 99, 424-433.

Levy, B.R. - Pilver, C.E. (2012): Residual stigma: Psychological distress among the formerly overweight. Social Science and Medicine, 75, 297-299.

Lindova, J. (2009): Pohled a ocni kontakt. In: Lidsky oblicej (eds. by Blazek, V. - Trnka, R.), pp. 155-158. Karolinum: Prague.

Maharani, D.A. - Rahardjo, A. (2012): Is the utilisation of dental care based on need or socioeconomic status? A study of dental care in Indonesia from 1999 to 2009. International Dental Journal, 62, 90-94.

Maner, J.K. - Mead, N.L. (2010): The Essential Tension Between Leadership and Power: When Leaders Sacrifice Group Goals for the Sake of Self-Interest. Journal of Personality and Social Psychology, 99, 482-497.

Manning, A. - Dawkins, M.S. (2009): An Introduction To Animal Behavior. Cambridge University Press: New York.

Manteuffel, G. - Mannewitz, A. - Manteuffel, C. - Tuchscherer, A. - Schrader, L. (2010): Social hierarchy affects the adaption of pregnant sows to a call feeding learning paradigm. Applied Animal Behaviour Science, 128, 30-36.

Mast, M.S. (2010): Interpersonal behaviour and social perception in a hierarchy: The interpersonal power and behaviour model. European Review of Social Psychology, 21, 1-33.

Mast, M.S. - Hall, J.A. - Roter, D.L. (2008): Caring and dominance affect participants' perceptions and behaviors during a virtual medical visit. Journal of General Internal Medicine, 23, 523-527.

Mazur, A. - Halper, C. - Udry, R.J. (1994): Dominant Looking Male Teenagers Copulate Earlier. In: Ethology and Sociobiology, pp. 87-94.

McFarland, D. (1981): The Oxford Companion to Animal Behavior. Oxford University Press: Oxford.

Mealey, L. (1985): The relationship between social status and biological success: A case study of the Mormon religious hierarchy. Ethology and Sociobiology, 6, 249-257.

Mehta, P.H. - DesJardins, N.M.L. - van Vugt, M. - Josephs, R.A. (2017): Hormonal underpinnings of status conflict: Testosterone and cortisol are related to decisions and satisfaction in the hawk-dove game. Hormones and Behavior, 92, 141-154.

Miyakawa, M. - Hanson, L.L.M. - Theorell, T. - Westerlund, H. (2012): Subjective social status: its determinants and association with health in the Swedish working population (the SLOSH study). European Journal of Public Health, 22, 593-597. 
Morrison, J. - Dulal, S. - Harris-Fry, H. - Basnet, M. - Sharma, N. - Shrestha, B. - Manandhar, D. - Costello, A. - Osrin, D. - Saville, N. (2018): Formative qualitative research to develop community-based interventions addressing low birth weight in the plains of Nepal. Public Health Nutrition, 21, 377-384.

Mueller, U.O. - Mazur, A. (1997): Facial dominance in Homo sapiens as honest signaling of male quality. Behav. Ecol, 569-579.

Nakamichi, M. - Koyama, N. (1997): Social relationships among ring-tailed lemurs (Lemur catta) in two free-ranging troops at Berenty Reserve, Madagascar. International Journal of Primatology, 18, 73-93.

O’Connor, L.E. - Berry, J.W. - Weiss, J. - Schweitzer, D. - Sevier, M. (2000): Survivor guilt, submissive behaviour and evolutionary theory: The down-side of winning in social comparison. British Journal of Medical Psychology, 73, 519-530.

Ocker, R.J. (2007): A balancing act: The interplay of status effects on dominance in virtual teams. Ieee Transactions on Professional Communication, $50,204-218$.

Ortiz-Hernandez, L. (2005): Influence of internalized oppression on the mental health of homosexuals, lesbians and bisexuals in Mexico City. Salud Mental, 28, 49-65.

Perrett, D.I. - Lee, K.J. - Penton-Voak, I. - Rowland, D. - Yoshikawa, S. Burt, D.M. - Henzi, S.P. - Castles, D.L. - Akamatsu, S. (1998): Effects of sexual dimorphism on facial attractiveness. Nature, 394, 884-887.

Perusse, D. (1993): Cultural and Reproductive Success in Industrial-Societies - Testing the Relationship at the Proximate and Ultimate Levels. Behavioral and Brain Sciences, 16, 267-283.

Pratto, F. - Sidanius, J. - Levin S. (2006): Social dominance theory and the dynamic of intergroup relations:Taking stock and looking forward. $\mathrm{Eu}$ ropean Review of Social Psychology, 271-320.

Reyes-Garcia, V. - Mcdade, T.W. - Molina, J.L. - Leonard, W.R. - Tanner S.N. - Huanca, T. - Godoy, R. (2008): Social rank and adult male nutritional status: Evidence of the social gradient in health from a foraging-farming society. Social Science and Medicine, 67, 2107-2115.

Ribbon, W. (2018): Power and Control Wheel. (online). https://www. whiteribbon. org. au/understand-domestic-violence/what-is-domestic-violence/ controlling-relationships/power-and-control-wheel.

Rohde, P. (2001): The relevance of hierarchies, territories, defeat for depression in humans: hypotheses and clinical predictions. Journal of Affective Disorders, 65, 221-230.

Rubin, P.H. (2000): Hierarchy. Human Nature-an Interdisciplinary Biosocial Perspective, 11, 259-279.

Sapolsky, R. (2019): Chování. Biologie člověka v dobrém i ve zlém. Dokořán s.r.o.: Praha.

Sapolsky, R.M. (2005): Sick of Poverty. Scientific American, 293, 92-99.

Sarova, R. - Spinka, M. - Panama, J.L.A. - Simecek, P. (2010): Graded leadership by dominant animals in a herd of female beef cattle on pasture. Animal Behaviour, 79, 1037-1045.

Sherman, G.D. - Lerner, J.S. - Josephs, R.A. - Renshon, J. - Gross, J.J. (2016): The Interaction of Testosterone and Cortisol Is Associated With Attained Status in Male Executives. Journal of Personality and Social Psychology, $110,921-929$.

Sherman, G.D. - Lerner, J.S. - Renshon, J. - Ma-Kellams, C. - Joel, S. (2015): Perceiving Others' Feelings: The Importance of Personality and Social Structure. Social Psychological and Personality Science, 6, 559-569.

Siart, B. - Pfluger, L. - Wallner, B. (2016): Pulling Rank: Military Rank Affects Hormone Levels and Fairness in an Allocation Experiment. Frontiers in Psychology, 7.

Sidanius, J. - Pratto, F. - Bobo, L. (1994): Social-Dominance Orientation and the Political Psychology of Gender - A Case of Invariance. Journal of Personality and Social Psychology, 67, 998-1011.
Soler, C. - Nunez, M. - Gutierrez, R. - Nunez, J. - Medina, P. - Sancho, M. Alvarez, J. - Nunez, A. (2003): Facial attractiveness in men provides clues to semen quality. Evolution and Human Behavior, 24, 199-207.

Soukup, V. (2011): Antropologie. Teorie člověka a kultury. Portál: Praha.

Thornhill, R. - Gangestad, S.W. (2006): Facial sexual dimorphism, developmental stability, and susceptibility to disease in men and women. Evolution and Human Behavior, 27, 131-144.

Thornhill, R. - Palmer, C.T. (2000): A natural history of rape. The MIT Press: Cambridge, England.

Thornhill, R. - Thornhill, N.W. (1992): The Evolutionary Psychology of Mens Coercive Sexuality. Behavioral and Brain Sciences, 15, 363-375.

Veselovský, Z. (2005): Etologie. Academia: Praha.

Voland, E. - Dunbar, R.I.M. (1995): Resource Competition and Reproduction - the Relationship Between Economic and Parental Strategies in the Krummhorn Population (1720-1874). Human Nature-an Interdisciplinary Biosocial Perspective, 6, 33-49.

Voland, E. - Siegelkow, E. - Engel, C. (1991): Cost-Benefit Oriented Parental Investment by High Status Families - the Krummhorn Case. Ethology and Sociobiology, 12, 105-118.

von Rueden, C. - Gurven, M. - Kaplan, H. (2008): The multiple dimensions of male social status in an Amazonian society. Evolution and Human Behavior, 29, 402-415.

von Rueden, C.R. - Jaeggi, A.V. (2016): Men's status and reproductive success in 33 nonindustrial societies: Effects of subsistence, marriage system, and reproductive strategy. Proceedings of the National Academy of Sciences of the United States of America, 113, 10824-10829.

Warren, J. - Stoerger, S. - Kelley, K. (2012): Longitudinal gender and age bias in a prominent amateur new media community. New Media \& Society, $14,7-27$.

Watts, I.- Nagy, M. - de Perera, T.B. - Biro, D. (2016): Misinformed leaders lose influence over pigeon flocks. Biology Letters, 12

Waynforth, D. (2001): Mate choice trade-offs and women's preference for physically attractive men. Human Nature-an Interdisciplinary Biosocial Perspective, 12, 207-219.

Wiggins, J.S. - Trapnell, P. - Phillips, N. (1988): Psychometric and Geometric Characteristics of the Revised Interpersonal Adjective Scales (Ias-R). Multivariate Behavioral Research, 23, 517-530.

Wight, R.G. - LeBlanc, A.J. - de Vries, B. - Detels, R. (2012): Stress and Mental Health Among Midlife and Older Gay-Identified Men. American Journal of Public Health, 102, 503-510.

Wolff, S.E. - Puts, D.A. (2010): Vocal masculinity is a robust dominance signal in men. Behavioral Ecology and Sociobiology, 64, 1673-1683.

\section{AUTORKY}

Doc. RNDr. Eva Jozífková, Ph.D. et Ph.D. vystudovala zoologii (PřF JCU), antropologii (PřF UK), lékařskou psychologii a psychopatologii (LF1 UK). Působí na PřF a FSE UJEP. Zkoumá dominanční hierarchie, evoluční př́ičiny sexuálních preferencí typu BDSM a chování zvířat. Kontakt: eva.jozifkova@ujep.cz

Mgr. Martina Koláčková, Ph.D. vystudovala parazitologii (PřF JCU) a imunologii (LFHK UK). V současnou chvíli působí na Ústavu klinické imunologie a alergologie na Lékařské fakultě v Hradci Králové. Přestože jejím hlavním zájmem je evoluce B lymfocytů, jejich ontogeneze a podíl na různých typech onemocnění, zajímá se o vliv imunitního systému na chování a vývoj člověka a lidské populace. Kontakt: kolackovam@lfhk.cuni.cz 